\title{
The Emergence of I
}

\author{
Andreas E. Masvie \\ University of Oxford, Oxford, UK \\ andreas.masvie@gmail.com
}

\begin{abstract}
Among the ancients, there was no proper conception of the I. Yet an I emerges in ancient Israel. I therefore inquire into the philosophical anthropology of ancient Israel. How did the I emerge? By interpreting the Song of Songs as political myth, from which a philosophical anthropology can be unearthed and reconstructed, I theorize that not only an I, but also a different kind of we emerged through gift-dynamics. Then I demonstrate that these gift-dynamics are compatible with the ancient Israelites' religiouspolitical institutions and manifest itself in their collective psyche.
\end{abstract}

\section{Keywords}

political myth - philosophical anthropology - ancient Israel - Song of Songs - gift theory

If I know $x$, then I am in some sort of conscious relation to $x$. And I can only be in a conscious relation to $\mathrm{x}$ from a certain perspective, from my perspective. This implies that there is no such thing as knowing $\mathrm{x}$ simpliciter, at the very least not for beings like ourselves. When I know $\mathrm{x}$, it is not identical to you knowing x. Indeed, I cannot even know what it is like for you to know x. Even though our perspectives are particular in this sense, they are universal in another. I can know what it is like for you to have knowledge of the world to which $\mathrm{x}$ belongs. That is, your perspective is not suigeneris, and neither is mine - or, so one can reasonably assume. Our perspectives are inexorably human perspectives. Thus, by virtue of being human, we participate in the world in the same manner, we share the same mode of being.

What characterizes our human mode of being? It appears to be a radical dualism: to be human is to exist as both I and we - to exist, as it were, as 
I-we. ${ }^{1}$ This dualism reveals itself in basic need-desires. On the one hand, there is the basic need-desire of the we: to be part of the community, to be one with others. On the other hand, there is the basic need-desire of the I: to be set apart from the community, to be someone in and of oneself.

However, in the beginning of history, societies did not cohere with the Iwe. Consider, for instance, the ancient Egyptians' notion of maat, a principle of order so comprehensive that 'it governed every aspect of existence.'. The pharaoh was the materialization of maat, and, therefore, if commoners were to align with maat, they had to align with the pharaoh. To controvert the pharaoh was to conspire against maat, to summon the forces of chaos. To perpetuate maat was to partake in the pharaoh's temple cult, to embrace one's place in the hierarchy of cosmos. ${ }^{3}$ In ancient Egypt, therefore, one could not really be set apart from the community, be someone in and of oneself. Commoners, priests and pharaoh were reducible to their role within society, precluding any I from emerging.

There is no reason to believe that other ancient Near Eastern societies were any different in this regard - hierarchies were legitimated cosmically in the entire ancient Near East. ${ }^{4}$ But in ancient Israel, this conceptual paradigm metamorphosed, as the Torah's theology of covenant provided the metaphysical conditions for ancient Israel 'to conceive of itself as a society devoid of the inherent and cosmically legitimated hierarchy found elsewhere. ${ }^{5}$ Ancient Israelites were 'present under' 6 the Lord God, both as I and we, and were therefore compelled to continuously consider whether their existence harmonized with the Lord God, whom they participated in a covenantal relationship with - that is, although ancient Israelites were commoners, priests and monarchs, much like other ancient Near Eastern societies, their existence, unlike these societies, was not reducible to their role within society. ${ }^{7}$

1 Tomasello, M. Becoming Human: A Theory of Ontogeny (Cambridge, Mass.: Belknap Press of Harvard University Press, 2019), 15 .

2 Cohn, N. Cosmos, Chaos and the World to Come: The Ancient Roots of Apocalyptic Faith, 2nd ed. (New Haven \& London: Yale University Press, 1993), 9.

3 Cohn, Cosmos, Chaos and the World to Come, 25.

4 Cohn, Cosmos, Chaos and the World to Come, 3-4.

5 Berman, J.A. Created Equal: How the Bible Broke with Ancient Political Thought (Oxford \& New York: Oxford University Press, 2008), 49.

6 Voegelin, E. Order and History Volume 1: Israel and Revelation (1956), in The Collected Works of Eric Voegelin Volume 14, ed. M.P. Hogan (Columbia \& London: University of Missouri Press, 2001), 405 .

7 Berman, Created Equal, chap. 1. 
Thus an I - and also, by extension, a we proper, as the distinctness of the we presumes the distinctness of the I and vice versa - emerged in ancient Israel.

But if so, then from what dynamics did this I emerge? Or, put differently, what philosophical anthropology enabled the emergence of the I? I shall argue that it was a philosophical anthropology of gift.

I begin by demonstrating that the Song of Songs can be interpreted as political myth, and that, from this myth, a philosophical anthropology of ancient Israel can be unearthed and reconstructed (section 1). Then, by interpreting the Song as political myth, I unearth its philosophical anthropology, and reconstruct its logic of gift-dynamics (section 2). Lastly, I contend that this philosophical anthropology is compatible with the religious-political institutions of ancient Israel and indeed describes a profound structure in their collective psyche (section 3$)$.

\section{The Song of Songs as Political Myth}

What does it mean to interpret the Song as political myth? Before answering this question, it is necessary to define the term 'political myth' itself. To do so, we must distinguish between two such concepts: political myth qua sociological process and qua philosophical method.

First, the sociological process. Bottici \& Challand follow Blumenberg in defining myth as a process of continual work on a simple, significant narrative. ${ }^{8}$ The process of continual work is a complex of creation-reception-recreation. What makes the myth a political myth qua sociological process 'is not its content or its claim to truth, but (1) the fact that it coagulates and reproduces significance; (2) that it is shared by a given group; and (3) that it can address the specifically political conditions in which a given group lives.' ${ }^{9}$ The distinction between 'truth' and 'significance' is however unhelpful. Surely, to assert that $\mathrm{x}$ is significant is to implicitly assert that $\mathrm{x}$ is true (the opposite would be absurd). I postulate, therefore, that political myths do make truth claims. Moreover, I assume that these political myths belong to the category of 'myth' as found within sociology - and thus that classical studies on the myth, such as those of Levi-Strauss and Malinowski, enable a fuller understanding of the political myth and its truth claims.

8 Bottici, C. \& B. Challand. 'Rethinking Political Myth: The Clash of Civilizations as a SelfFulfilling Prophecy'. European Journal of Social Theory 9:3 (2006), 315-336: 318; Bottici, C. A Philosophy of Political Myth (Cambridge: Cambridge University Press, 2007), 7.

9 Bottici \& Challand, 'Rethinking Political Myth', 320. 
Second, the philosophical method. I define political myth qua philosophical method as stories depicting the movement from human struggle to human flourishing (or vice versa) - stories through which one can inquire into human nature in general and flourishing in particular. The most prominent examples of such stories are concerned with the hypothetical transition from pre-society to society and are found in the thought of philosophers à la Hobbes, Locke and Rousseau. Moving from struggle to flourishing demands a descriptivenormative anthropology: a philosophical anthropology. Coincidentally, this category of political myth often satisfies Bottici \& Challand's three aforementioned criteria: the stories' philosophical anthropology (1) coagulates and reproduces significance by being continually discussed in academic and political circles; (2) is shared by the group of philosophers and politicians who believe in it; and (3) ex hypothesi address the political conditions in which the group lives.

The two categories of political myth can thus be fused. And I do so by applying a slightly adjusted and specified version of Bottici \& Challand's definition: I concentrate on the Song's philosophical anthropology, hereafter simply 'anthropology', and furthermore, on the anthropology's compatibility with the religious-political institutions and manifestation in the collective psyche of ancient Israel. And the reason for doing so is to understand, firstly, how the Song envisages that humans should be in order to become imago Dei, and secondly, if an I emerges from this notion of the imago Dei.

Immediately, some might object that my approach is futile: to interpret the Song as political myth is to impose a foreign category onto the text. This objection is really twofold, and therefore demands a twofold response.

First, can the Song be interpreted as political myth? The Song is not a story as such. Rather, it is a lyric-poetic dialogue between two $^{10}$ lovers, a Bride and her Bridegroom. But as the two lovers engage with one another, there are movements from struggle to flourishing, and sometimes also back to struggle - movements which the reader-listener are drawn into via the Bride, the protagonist. The Song is about these movements, ripe with mythological elements, ${ }^{11}$ part of a greater theological narrative concerning the nature of both humans and the Lord God. And this theological narrative develops throughout the various texts of the Tanakh. The political myth of the Song cannot, therefore, be cut off its larger corpus. Quite the contrary, like all myths, the Song belongs to a complex

10 Davidson, R.M. Flame of Yahweh: Sexuality in the Old Testament (Peabody, Mass.: Baker Publishing Group, 2007), 587 .

11 Landy, F. Paradoxes of Paradise: Identity and Difference in the Song of Songs, 2 nd ed. (Sheffield: Sheffield Phoenix Press, 2011), chap. 4. 
of myths attempting to express the inexpressible, attempting to reach to the very depths of creation in general, and our being in particular. Any structure 'which occurs in one myth will recur, in the same or other variations, in other parts of the complex.. ${ }^{12}$ And, moreover, this complex cannot be properly understood except in relation to relevant social structures. ${ }^{13}$

Second, can the Song be interpreted as political myth? If there is indeed movement from struggle to flourishing, then the Song necessarily (albeit perhaps implicitly) concerns anthropology. This, in itself, implies that the Song is political: political theory is inevitably predicated on a certain anthropology, and thus anthropology is inevitably - indirectly - political. Furthermore, by exploring the inner workings of the conjugal covenant, the writer-redactor explores (albeit perhaps subconsciously) ${ }^{14}$ the inner workings of society at large. Covenants bind together A and B through promises of commitment, and in ancient Israel, all sorts of communities unfolded within covenants - be they cosmic, religious-political or conjugal. ${ }^{15}$ Of these covenants, the conjugal covenant is paradigmatic. ${ }^{16}$ It is not paradigmatic in a sense suggesting cultic sexualization qua genitalization: when offering sacrifice, for instance, the priests were commanded to clothe themselves with 'linen undergarments to cover their naked flesh; they shall reach from the hips to the thighs' (Ex. 28:42-43). Rather, the conjugal covenant is paradigmatic in the sense that it reveals the inner workings of the cosmic and religious-political covenants (e.g. Ez. 16; Hos. 2). By exploring the inner workings of the conjugal covenant, the Song therefore explores the inner workings of communities per se, and thus society at large.

One can even make the case, that to interpret the Song as political myth is a comme il faut continuation of the Song's reception history. The manifold ${ }^{17}$ interpretations that compose the Song's reception history can be categorized either as 'praise song' or 'love poem'. Centering on divine love, the praise song is an allegorical interpretation, which approaches the Bride-Bridegroom in

\footnotetext{
12 Leach, E. Genesis as Myth and Other Essays (London: Jonathan Cape Ltd., 1969), 22.

13 Malinowski, B. Sex, Culture, and Myth (London: Rupert Hart-Davis, 1963), 292.

14 Lévi-Strauss, C. 'Structuralism and Myth'. The Kenyon Review, New Series 3:2 (1981), 65-88: 66 .

15 Gentry, P.J. \& S.J. Wellum. Kingdom Through Covenant: A Biblical-Theological Understanding of the Covenants (Wheaton, Ill.: Crossway, 2012), chap. 4.

16 Gentry \& Wellum, Kingdom Through Covenant, 133.

17 Garrett, D. Song of Songs and Lamentations: Word Biblical Commentary vol. 23b, ed. B.M. Metzger, J.D.W. Watts \& J.W. Watts (Nashville: T. Nelson, 2004), 59-91; Davidson, Flame of Yahweh, 545-551. For an analysis of Luther's allegorical-political interpretation (which is, to my knowledge, the only other political interpretation there is): Carty, J.A. 'Martin Luther's Political Interpretation of the Song of Songs'. The Review of Politics 73:3 (2011), 449-467.
} 
terms of a human-divine relationship. The love poem, by contrast, is a literal interpretation, finding erotic love to be the Song's central concern, and thus approaches the Bride-Bridegroom in terms of an interhuman relationship. By proposing a third category of interpretation, that of political myth, I am not dismissing these categories of interpretation. To explore the Song's anthropology, the political myth approaches the Bride-Bridegroom in terms of a creationhuman-divine relationship, transcending the allegorical-literal dichotomy: the allegorical and the literal edifies one another. To interpret the Song as political myth, therefore, the reader-listener must enter an epistemic circularity. To know the allegorical, one must know the literal, and to know the literal, one must know the allegorical. Such epistemic circularities were not unknown to the ancient Israelites: their anthropology is theomorphic, and their theology anthropomorphic - epitomized precisely in the imago Dei.

The Song's epistemic circularity mirrors its metaphysical circularity, namely that of gift-dynamics, which I argue to be the essence of the Song's anthropology: to be imago Dei is to participate in mutual and absolute gift-dynamics. ${ }^{18}$ Since the gift is the kernel of my interpretation of the Song, I must briefly expound on the gift's ontology, so as to ensure that the concept is lucid. What are the gift's necessary and sufficient conditions? Consider: A gives $\mathrm{x}$ to $\mathrm{B}$. If $\mathrm{x}$ is gift, then A must submit ownership to B. If ownership does not truly exist, then there can be no real submission, and thus no gift. Also, this submission must be of a specific kind, it must be free. If A does not freely submit $x$, then the gift is de facto theft. If $\mathrm{B}$ does not freely receive $\mathrm{x}$, then $\mathrm{x}$ is not really submitted. In either case, there is no gift. And free submission of ownership cannot occur without gift-dynamics occurring, nor can gift-dynamics occur without free submission of ownership occurring. I postulate, therefore, that $x$ is gift if and only if $\mathrm{x}$ is free submission of ownership. Thus, what is 'gift' (and whether the gift can exist, which certain scholars dispute $)^{19}$ diverges with different conceptions of ownership and freedom. Moreover, I take it to be a fact that the gift cannot be reduced to that which is given. ${ }^{20} \mathrm{I}$ assume that this is because the gift's essential purpose is to create and deepen relations. A's gift to B constitutes and substan-

18 Cf. John Paul II. Man and Woman he Created Them: A Theology of the Body, transl. M. Waldstein (Boston: Pauline Books \& Media, 2006), esp. chap. 1.5.

19 Bourdieu, P. Outline of a Theory of Practice, transl. Richard Nice (Cambridge: Cambridge University Press, 1977), 1-30; Derrida, J. Given Time, 1: Counterfeit Money, transl. P. Kamuf (Chicago: University of Chicago Press, 1992), e.g. 15. For the opposing argument: Milbank, J. 'Can a Gift Be Given? Prolegomena to a Future Trinitarian Metaphysics'. Modern Theology 11:1 (1995), 119-161: esp. 119-144.

20 Mauss, M. The Gift: Forms and Functions of Exchange in Archaic Societies (1954), transl. I. Cunnison (Glencoe, Illinois: The Free Press, 2011), 3. 
tiates the A-B relation. If $\mathrm{A}$ gives $\mathrm{x}$ to $\mathrm{B}$, then $\mathrm{A}$ creates or deepens a relation with $B$, which is to hope that $B$ reciprocates. If the gift is not reciprocated, then the gift's potential is unactualized.

As we turn to the political myth of the Song, I shall briefly draw attention to a significant difference between the Song's anthropology, and that of Hobbes, Locke and Rousseau. In the political myths of Hobbes, Locke and Rousseau, the institutions actively facilitate flourishing. Indeed, it is the institutions rather than the humans that bring about flourishing: Hobbes argued that humans flourish when the state prevents war against all, Locke when the state protects certain rights and Rousseau when the state directs the general will. In the Song, however, the institutions facilitate flourishing passively: the contractual aspects of the conjugal covenant are assumed to be necessary, ${ }^{21}$ but they are not at all sufficient for bringing about flourishing. Flourishing also necessitates the active participation of the Bride and Bridegroom: when the active participation dies, so does the flourishing. This active participation is captured in the Talmudic legal-ethical principle of 'going beyond the limits of the law, ${ }^{22}$ wherein lies the Song's anthropology, to which we now turn.

\section{$2 \quad$ The Gift Theory of the Song}

To concentrate on the Song's anthropology is to concern oneself with cosmic matters: humans cannot really flourish without creation at large flourishing. And the intricate garden imagery - which is the Song's primary ${ }^{23}$ image - compels the reader-listener precisely to do so. On the one hand, it is quite evident that the garden signifies the Bride, and more specifically, her erotic being. ${ }^{24}$ As such, the garden is a place of conjugal consummation. On the other hand, the garden of the Song clearly alludes to the garden of Eden. ${ }^{25}$ And the garden of Eden is the archetypical sanctuary, ${ }^{26}$ the place of cosmic consummation. Here

\footnotetext{
21 Davidson, Flame of Yahweh, 46.

22 Mittleman, A.L. A Short History of Jewish Ethics: Conduct and Character in the Context of Covenant (Chichester \& Malden: Wiley-Blackwell, 2012), 78.

23 Hess, R.S. Song of Songs: Baker Commentary on the Old Testament Wisdom and Psalms, ed. T. Longman III (Michigan: Baker Academics, 2005), 156.

24 Longman III, T. Song of Songs: The New International Commentary on the Old Testament (Grand Rapids, Mich.: William B. Eerdmans Publishing Company, 2001), 155.

25 Trible, P. 'Depatriarchalizing in Biblical Narrative'. Journal of the American Academy of Religion 41:1 (1973), 30-48: 42-47; Davidson, Flame of Yahweh, 552-556.

26 Wenham, G.J. Genesis 1-15: Word Biblical Commentary vol. 1 (Waco, Tex.: Word Books, 1987), 86 .
} 
I must offer a semantic clarification. In using the term 'consummation', I refer to an allegorical-literal naked embrace, that is, giving oneself to the other, and receiving the other's gift of self. I shall use the term 'singularity' when referring to instances of such mutual and absolute gift-dynamics. The consummation, therefore, is the bringing about of singularity.

By alluding to the garden of Eden, the Song does not only invoke cosmic concerns, it also evokes a sense of universality. Through Eden, the element of origin saturates the Song - and origin stories are told partly for their universality. By making claims about the original humans, one inevitably makes claims about subsequent humans. In the Song, these universal claims are meditations on sex in particular, and the singularity in general, to which the Song gravitates both thematically and structurally (Song. 4:16-5:1). ${ }^{27}$ In the naked embrace, the Bride opens her garden, enabling the Bridegroom to allegorically and literally come into her (Song. 5:1). The chorus - which 'is the voice of those outside the relationship'28 - encourages and celebrates, as if participating through witness: 'friends, drink, and be drunk with love' (Song. 5:1). The Song's structure thus accentuates the communal significance of the conjugal consummation. More crucially, the structure exposes the conjugal consummation's prophetic element: in the cosmic consummation, the participation of crowds does not oppose the intimacy of the I-you.

The anthropology of the Song takes form in this singularity. From the outside, the reader-listener will 'grasp nothing of its inner significance. ${ }^{29} \mathrm{I}$ attempt, therefore, to do analytically what the Song does lyrically-poetically: moving into the logic of the singularity, into the 'enchanting interfusions' ${ }^{30}$ of the allegorical-literal garden, into the 'Holy of Holies' (m. Yad. 3:5). Here, the readerlistener senses shalom, the essential property of the singularity, ${ }^{31}$ this deepening harmony amongst the Lord God, humans and creation - this equilibrium that comes from fulfillment of being. ${ }^{32}$ And the Song's rhythmic play on words like 'Shulamite', 'Solomon', and 'shalom' (e.g. Song 1:1, 5; 3:7, 9, 11; 6:13; 8:10-12) arouses the reader-listener's longing for such fulfilment. ${ }^{33}$

The Song's singularity is not, however, some sort of fixed equilibrium, once entered, forever constant. In the Song, the singularity demands continuous

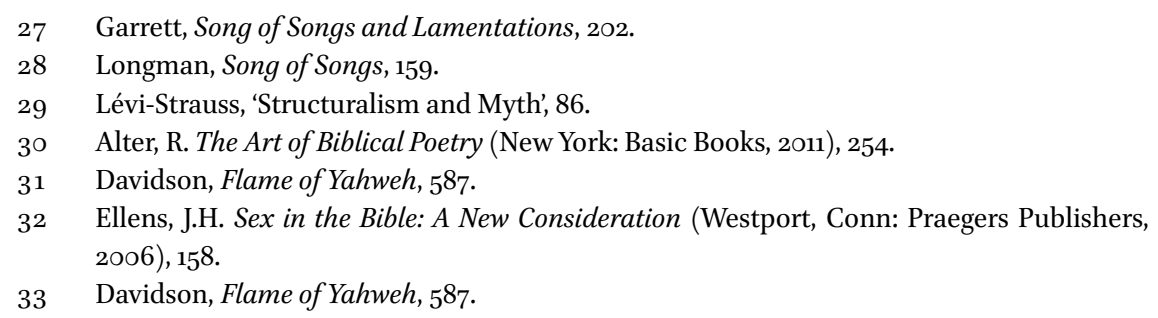


participation. This is captured in the messy movement between struggle and flourishing (e.g. Song $2: 11,15 ; 3: 1-4 ; 5: 6-8 ; 6: 1$ ), it is not deterministc, it is not sterile. Indeed, in the Song, as the lovers come close, some messiness appears to be unavoidable. The very act of undressing, allegorically and literally standing naked before the other, implies exposure of one's inner self. And such exposure stirs fear. Do I entrust the other with my nakedness? With my shame? In Eden, the lovers were created into the singularity, and they were 'not ashamed' (Gen. 2:25). In the Song the lovers must overcome the trials that prevent participation in the singularity. They must continuously expose by expressing their needs and desires - honestly (e.g. Song 2:6) yet honorably (e.g. Song 2:7) - so as to enable the other to tend to these. And, simultaneously, they must listen to the need-desires of the other and strive to tend to these also. Sometimes, however, one does not tend to the need-desires of the other, be it a matter of inattentiveness, neglect, or mischief. And sometimes, one uses the other as a tool for pleasing and satisfying oneself. Such messiness opposes flourishing. It is sinning against the other. In the garden of the Song, the serpent is not simply around the lovers, it is also within. And sinning against the other is exiling oneself from the singularity, which humans do even amidst ecstasy (Song. $5: 2-4)$. To come back into the singularity, one must give the gift of repentance, and the other must reciprocate the gift of forgiveness (Song. 5:6 ff.). Thus, the singularity is a dynamic equilibrium: it is continuously drawing closer to one another.

From beginning to end, the lovers of the Song flourish when they participate in gift-dynamics. Both give and receive, ${ }^{34}$ climaxing in the giving and receiving of self (Song. 4:16-5:1). And in order to do so, they must bind a bond of exclusivity, ${ }^{35}$ without which their naked embrace cannot be properly creative. 'My beloved is mine and I am his' (Song. 2:16). If the Bride worries that the Bridegroom might reject the shame of her naked self, and perhaps even uncover it so that others reject her as well, then the Bride might not dare to properly selfexpose; she might not dare to make a fool of herself in the solemn comics of sex. But the Bridegroom has bound himself to the Bride - and so has the Bride to the Bridegroom. She therefore dares to let him come into her nakedness. And upon coming into the Bride's nakedness, pleasing and satisfying becomes just as important as being pleased and satisfied; she has become the extension of

34 Lacocque, A. Romance, She Wrote: A Hermeneutical Essay on Song of Songs (Harrisburg, Pa.: Trinity Press International, 1998), 115.

35 Garrett, D.A. Proverbs, Ecclesiastes, Songs of Songs: New American Commentary (Nashville: Broadman and Holman, 1997), 379. 
himself. They belong to one another. 'There are sixty queens and eighty concubines, and maidens without number' (Song. 6:8), exclaims the Bridegroom, before insisting: my Bride, 'the perfect one, is the only one' (Song. 6:9), simply because she is his. This ownership is not in the slightest intrusive or dominating. On the contrary, the Bridegroom respectfully guards the Bride's freedom. 'A garden locked is my sister, my bride, a garden locked' (Song. 4:12). The Bridegroom does not break the garden open. Some might object that more than anything else, the locked garden is about patriarchal containment. It can be responded that it is the Bride herself that unlocks the garden, neither her father nor her brothers. 'Let my beloved come to his garden', the Bride urges, 'and eat its choicest fruits' (Song. 4:16). Excited and elated, the Bridegroom receives the Bride's gift: 'I come to my garden' (Song. 5:1). The Bride and Bridegroom thus freely submit ownership of themselves to the other; they participate in mutual and absolute gift-dynamics, that is, in the singularity.

What is the purpose of participating in such mutual and absolute giftdynamics? It is to become imago Dei. And to become imago Dei is to worship the Lord God cohesively, to give the Lord God all. Worship of the Lord God is thus not confined to cultic rituals - it is also to continuously rejoice in the imago Dei, the Lord God in humans. In the Song, such rejoicing is a twofold gift-dynamic reflecting the normative-descriptive imago Dei of Genesis $1^{36}$

First, reflecting the normativity, one must become who and what one is created to be also by enabling the other to be who and what they are created to be. This dynamic is captured by the fact that the Bride and Bridegroom are constitutive of each other (e.g. Song 2:16). ${ }^{37}$ The unification of the binaries constitute a simple whole which is completed in the imago Dei. ${ }^{38}$ And enabling the other to become who and what they are created to be is a matter of giving one another appropriate gifts - where the gift's 'appropriateness' 39 is determined in part by nature, in part by culture. It is not appropriate for the Bride to give the

36 Middleton, J.R. The Liberating Image: The Imago Dei in Genesis 1 (Grand Rapids, Mich.: Brazos Press, 2005), 88.

37 Trible, 'Depatriarchalizing in Biblical Narrative', 45; Fox, M.V. The Song of Songs and the Ancient Egyptian Love Songs (Madison, Wis.: University of Wisconsin Press, 1985), 315-318; Dorsey, D.A. Literary Structure of the Old Testament: A Commentary on Genesis-Malachi (Grand Rapids, Mich.: Baker Academic, 2007), 213.

38 Davidson, Flame of Yahweh, 19-22.

39 Clements, R.E. Old Testament Theology: A Fresh Approach (Eugene: Wipf and Stock Publishers, 2012), 33 . 
same gifts to her father and brother, for instance, as the gifts she gives to her Bridegroom. To give appropriate gifts is to uphold the order of creation, or, if one were to be anachronistic, its logos. But it is also to be creative within that order: since gifts constitute and substantiate relationships, one can alter the character of any given relationship by altering the gifts one gives. Foes can become friends, for instance, if they begin to give one another gifts such as compassion and hospitality. The gift's dual function - of upholding the order of creation as well as being creative within that order - is exposed in the mythical complex of the Tanakh, and perhaps especially clearly in the interaction between the Lord God and Noah immediately following the flood (Gen. 8:20). Noah's sacrifice upholds the order of creation by acknowledging and affirming the Lord God's distinctions, such as clean versus unclean. Moreover, Noah is creative within that order; no sacrifice is requested, but Noah desires to please and satisfy the Lord God, his being needs unity with the Lord God. And this brings about a change in the relationship between the Lord God and Noah: when the Lord God smelt the pleasing odor, then the Lord God avowed never again to curse the ground because of humans, or destroy every living creature (Gen. 8:21-22). The sacrifice therefore disrupts the recurring rebellion that the pre-patriarchal myths evolve around, that is the various rebellions against the Lord God's order of creation, which is also to reject to be creative within that order. After Eden, humans attempt to establish other orders, blurring the distinction between creator and created - be it via sexual intercourse with divine beings (Gen. 6:1-7) or reaching into the divine realms (Gen. 11:1-9). This rebellion resumes immediately after Noah's sacrifice (Gen. 9:20-23), as well as in the patriarchal myths and beyond.

Second, reflecting the descriptiveness, one must adore and exalt the other, because the other, being imago Dei, is worthy of such adoration and exaltation. Amongst humans, this is perhaps the most appropriate gift of all, radically captured by the movements of the Bridegroom's attention: from her lips (Song. 4:3) to her neck (Song. 4:4) to her breasts (Song. 4:5) to her vulva (Song. 4:12; 5:1). When coming to the vulva, the Bridegroom exclaims 'I eat my honeycomb' (Song. 5:1). In the ancient Near East, the metaphor of 'honeycomb' refers to the 'private parts of the lower female genitalia'. ${ }^{40}$ It is difficult to know whether to interpret 'eat' allegorically or literally. ${ }^{41}$ It is especially difficult because the imagery of eating honeycomb with honey is rather 'puzzling.42 But precisely because it is puzzling, one cannot dismiss the possib-

40 Gledhill, T. The Message of the Song: The Lyrics of Love (Leicester: Inter-Varsity, 1994), 167.

41 Longman, Song of Songs, 158.

42 Pope, M.H. Song of Songs (Garden City, N.Y.: Doubleday, 1977), 505. 
ility that the Bridegroom orally stimulates the Bride's vulva, and thus 'daringly challenges the taboo'.43 Indeed, how can there be a more appropriate gift? In the garden of Eden, the lovers broke the commandments of the Lord God, exiling themselves from the singularity. In the garden of the Song, the lovers break the taboo of humans, enabling the return from exile. This would explain why 5:1 speaks of both 'honeycomb' and 'honey'. On the one hand, the vertical myrrh-honeycomb-wine triad describes sexual intimacy. Myrrh can 'suggest a woman's natural fluids',44 and the wine thus depicts these fluids as intoxicating - the connection between alcohol and sex in general, and oral sex in particular, is not uncommon in the ancient Near East. ${ }^{45}$ On the other hand, the vertical spice-honey-milk triad educes connotations of the promised land's abundance. ${ }^{46}$ And if so, then the Song entwines the prophecy with that which is being prophesied, the conjugal consummation with the cosmic consummation.

The radicality of the writer-redactor's possible - even plausible - reference to oral sex, and more specifically cunnilingus, demands that we lend it further consideration. Given the cultural-historical context of the Song, there is, as suggested, hardly a more profound adoration and exaltation of the other within the conjugal covenant, than to give cunnilingus. The Bridegroom defies the customs of patriarchy, and does not use the Bride for stimulation or impregnation. Within patriarchy, therefore, cunnilingus elicits celibacy: in the eyes of the world, the man humiliates himself before the woman as he sacrifices his alleged entitlements - and in the Song, the Bridegroom delights in doing so, because he is being drawn closer to the Bride. She opens her garden to him, so that he can tend to it and eat of its fruits. She gives herself to him, so that he can give himself to her. She is the only woman he adores, she is the only woman he exalts. Consider the ownership and freedom demanded by such adoration and exaltation. By freely pleasing and satisfying the Bride, the Bridegroom finds pleasure and satisfaction himself. Since the Bride belongs to the Bridegroom, and these are her delights, they are also his delights. The Bride delights in being delighted by the Bridegroom; the Bridegroom delights in delighting the Bride because the Bride delights in being delighted by him; and the Bride's delight

\footnotetext{
43 Lacocque, Romance, She Wrote, 114. For the opposing argument: Veenker, R.A. 'Forbidden Fruit: Ancient Near Eastern Sexual Metaphors'. Hebrew Union College Annual 70/71 One Hundred Twenty-Fifth Anniversary (1999-200o), 57-73: 65 .

44 Garrett, Song of Songs and Lamentations, 210-211.

45 Moorey, P.R.S. 'The Terracotta Plaques from Kish and Hursagkalama, c. 185 o to 165 о в.C.' British Institute for the Study of Iraq 37:2 (1975), 79-99: 91-92.

46 Lacocque, Romance, She Wrote, 114. For the opposing argument: Longman, Song of Songs, 154 .
} 
deepens further because the Bridegroom delights in delighting her. Here, in the circularity of mutual and absolute giving and receiving - in the singularity the boundaries between the Bride and Bridegroom melt. This melting is made tangible by the fact that their love has the power of overflowing into the being whom might be conceived in their singularity. Yet from the very same singularity, I shall argue, the I emerges: the lovers become part of one another as well as being set apart from one another. ${ }^{47}$

I begin with our protagonist. The Bride becomes a we if and only if her need-desires melt together with the Bridegroom's need-desires, otherwise their beings would be in conflict. But she cannot force the Bridegroom to melt together with her need-desires, he must freely do so. Thus, if she is to become a we, then she must melt together with his need-desires - she must approach him with the intention that 'I will make your need-desires my own'. To act on this intention is to give oneself to the other. She no longer belongs to herself. She is part of him. And upon receiving her gift of self, the Bridegroom becomes an I. The Bride melts together with his need-desires rather than someone else's. She sets him apart from others. And upon receiving her gift, reciprocity is expected - which the Bridegroom does; he gives himself to her. As he does so, the Bridegroom becomes a we, and the Bride an I.

In the garden of the Song, therefore, the lovers are drawn into the singularity, where they emerge as I-we. And the meaning of this emergence is elucidated by intricate garden symbolism in general, and more particularly: tree symbolism. ${ }^{48}$ In Genesis 1, for instance, the structure emphasizes the closure of the third (Gen. 1:11-12) and sixth day (Gen. 1:26-29), ${ }^{49}$ so that humans, though imago Dei, are likened to trees (cf. Ps. 1:3). When rooted in fertile soil and pruned by the good gardener, their potential is actualized: they bring forth fruit. Thus, when the lovers delight in eating one another's fruits, they become who and what they were created to be. Indeed, to emerge as I-we is to eat the fruits of knowledge and life - thus symbolically inverting the sin and reverting the judgment of Eden. ${ }^{50}$ First, the reversion of judgement: the woman is desired and needed by a man who sacrifices himself for her rather than desiring and needing a man who dominates her (Gen. 3:16), enabeling the lovers to come alive

47 Davidson, Flame of Yahweh, 581.

48 Cf. Osborne, W.R. Trees and Kings: A Comparative Analysis of Tree Imagery in Israel's Prophetic Tradition and the Ancient Near East (University Park, Pennsylvania: Eisenbrauns 2018), esp. chap. 3; cf. Stordalen, T. Echoes of Eden: Genesis 2-3 and Symbolism of the Eden Garden in Biblical Hebrew Literature (Leuven: Peeters, 2000), esp. chap. 8-16.

49 Wenham, Genesis 1-15, 6.

$5^{\circ} \quad$ Landy, Paradox and Paradise, 204-205. 
again (e.g. Song. 4:15; cf. Gen. 2:7)..$^{51}$ Second, the inversion of sin: the lovemaking enables the lovers a transformed knowledge of oneself, the other and the Lord God, so that they in fact can become imago Dei.

Such knowing prompts an analysis of 'knowledge' (דעת), and its corresponding verb 'to know' (ידע), which may also connote sexually intimacy. ${ }^{52}$ While in Eden, Adam and Eve were tempted by the serpent's knowledge, and in order to gain it, they exiled themselves from the singularity. Their fatal mistake was rejecting to appreciate that participation in the singularity is to have everdeepening knowledge of the Lord God. In Genesis 2-3, this exile is reflected in two transitions. First, the transition from nakedness to hiding and covering. Secondly, the transition from calling the Lord God by the name Yahweh Elohim - where Yahweh captures the covenantal lover, and Elohim captures the holy creator - to calling the Lord God simply Elohim, rendering the Lord God aloof and unapproachable. Thus, Adam and Eve estranged themselves from the Lord God, each other, and their very self: a state of utter confusion. By being allured so as to abandon the one to whom they were bound, Adam and Eve exiled themselves from the garden of shalom. Since then, all their relationships are haunted by the doubt of the adulterer: will this one be unfaithful as I were? There is no more shalom, therefore, because there is a never-ending fear of rejection: in part because they have torn to pieces their will and ability to trust, in part because their being is indeed sinful and thus in fact abhorrent. That is, Adam and Eve exiled themselves from the fertile, fruitful garden of shalom to a lonesome, barren wilderness.

Later, when Hosea prophecies about the coming cosmic covenant, originally transgressed by Adam (Hos. 6:7), the Lord God declares that 'I will make you lie down in safety' (Hos. 2:18), despite the fact that humans continue to betray the Lord God: 'I will take you for my wife in righteousness and in justice, in steadfast love, and in mercy. I will take you for my wife in faithfulness; and you shall know the Lord' (Hos. 2:19-2o; cf. Ez. 16:8). One cannot ignore Hosea's 'sexual overtones'.53 Indeed, coincidentally, Hosea 2:18-19 comes as a perfect response to the Bride's longing for order, a garden where she might lie down in safety with her Bridegroom. 'O you who dwell in the gardens' (Song. 8:13), come and take me away from the confusing trials of history. 'Make haste, my beloved' (Song. 8:14). The coming cosmic covenant is thus depicted as a transformed garden, a

51 Garrett, Song of Songs and Lamentations, 201.

52 Botterweck, G.J. 'ידָע', in Theological Dictionary of the Old Testament Volume V, ed. G.J. Botterweck \& H. Ringgren, transl. D.E. Green (Grand Rapids \& Cambridge: Wm. B. Eerdmans Publishing Co., 2004).

53 Stuart, D. Hosea-Jonah: Word Biblical Commentary (Waco, Tex.: Word Books, 1987), 6o. 
cosmic sanctuary where there is transformed knowledge of the Lord God, the other and oneself.

This analysis of knowing prompts a further analysis, as knoweldge is elsewhere in the Tanakh defined in terms of fear rather than love. 'Fear of the Lord is the beginning of knowledge' (Prov. 1:7, cf. Deut. 10:12-13). To fear the Lord God is 'to acknowledge one's subordinate and dependent place in the universe, ${ }^{54}$ it is more like awe and wonder than respect or terror. Loving the Lord God, therefore, does not negate fearing the Lord God. Indeed, in order to properly love the Lord God qua the Lord God, one must fear the Lord God, otherwise it is not really the Lord God that one loves. A reflection of such love-fear is captured in the initial conjugal consummation of the Bride and Bridegroom. At last, after having publicly made the promises of their conjugal covenant, the Bride and Bridegroom are alone. And as they undress, there is burning love for the other's nakedness, a need-desire to come into this nakedness, but also a quivering fear of exposing one's nakedness. And while loving-fearing, they embrace one another; as she delights in opening up for him, and he delights in coming into her, the Bridegroom cuts through the Bride's flesh with a love that simultaneously burns and quivers (Song. 8:6; cf. Gen. 15:17-18). And as they come to know the other more deeply, and are known by the other more deeply, the ecstasy deepens - and rises as a 'pleasing odor' (e.g. Gen. 8:21).

The Song, therefore, draws the reader-listener into the singularity, whose essential property is shalom, urging them to participate in mutual and absolute gift-dynamics. These are cosmic gift-dynamics, revealed in the conjugal consummation. Here, in the conjugal consummation, the Bride and Bridegroom freely submit ownership of self to the other. They become gifts. And in doing so, the Bride and Bridegroom emerge simultaneously as I and we. By receiving the other, one is set apart from the others, which is to become an I. By giving oneself to the other, one becomes part of the other, which is to become a we. And this is the gift theory of the Song: to be imago Dei is to participate in mutual and absolute gift-dynamics. And from these gift-dynamics, the I-we emerges.

Through its gift-dynamics, the Song enables an I-we to emerge. But if these literary dynamics are suggestive of historic dynamics, then the ancient Israelites must have been drawn into the singularity. How might this have occurred?

54 Longman III, T. 'Proverbs 1: Book of', in Dictionary of the Old Testament: Wisdom, Poetry and Writings, ed. T. Longman III \& P. Enns (Downers Grove, Illinois: InterVarsity Press, 2008), 549 . 
As envisaged in the Song, the singularity could unfold within the conjugal covenant if - and only if - the spouses became 'one flesh' (Gen. 2:24). To be one flesh is to be in 'harmony and union with each other in all things'. ${ }^{55}$ Thus, becoming one flesh is only feasible if the spouses' mutual ownership is freely submitted to the other, if there is need and desire to enter the conjugal covenant. That is, becoming one flesh demands free submission of ownership, which is per se gift-dynamics. And if the spouses participate in such gift-dynamics, so as to overcome the patriarchic propensity for entitlement, then their lovemaking would be an experience of the singularity: as the lovers move 'through the sexual response cycle, from initial excitement to orgasm, ${ }^{\prime 6}$ oxytocin is released, culminating with the lovers' climax. And the release of oxytocin during sex captures the ecstatic awakening of the I-we, and its contingency on mutual and absolute gift-giving: with the release of oxytocin, there is an experience of I through sharpened 'self-other perceptual boundary' 57 simultaneously as there is an experiece of we through increased emotional 'bonding. ${ }^{58}$ But alas, how incomplete and imperfect this experience is.

The climax of sex could arouse a longing for something else, something more - yet something fundamentally similar. But it could hardly, in itself, enable an I-we to emerge. How, then, might the ancient Israelites have been drawn into the singularity? I shall argue that the singularity transpires in the cognitive realm that supervenes on narratives shared among the ancient Israelites.

I begin by arguing that the ancient Israelite religious-political institutions were compatible with the gift theory. Then I argue that the gift theory describes a profound structure in the ancient Israelite collective psyche. My argument does not, I should specify, concern when or even how the gift theory came to be such a structure; my argument is merely that such a structure existed - at the very least for ancient Israelites familiar with the canonical Tanakh, and perhaps even the canonical Torah. Here, I must make a Bermanian ${ }^{59}$ assumption: the gift theory reconstructs the gist (qua some sort of normative principle) of single writer-redactors, schools, or perhaps specific societal segments. But in turn, this gist began to form society at large. Furthermore, I must emphasize that, although unearthed from the Song, the gift theory is obviously a reconstruction and thus precisely that, a construct. Moderns can of course

55 Davidson, Flame of Yahweh, 47.

56 Crooks, R. \& K. Baur. Our Sexuality, 1oth ed. (Belmont: Wadsworth, 2008), 138.

57 Colonnello, V. et al. 'Oxytocin Sharpens Self-Other Perceptual Boundary'. Psychoneuroendocrinology 38:12 (2013), 2996-3002: 2999.

58 Crooks \& Karla, Our Sexuality, 138.

59 Berman, Created Equal, 7. 
never enter the ancients' cognitive realms; the immense epistemic void cannot be crossed. Discerning the ancients' cognitive realms inevitably demands reconstruction - it is the only method there is.

I have already elaborated briefly on the ontology of the gift: there must be ownership and freedom. And the Decalogue's rationale - this 'foundation of morality' 60 in general, and ancient Israelite legislation in particular - is precisely one of ownership and freedom, implying that the ancient Israelite religious-political institutions were compatible with the gift theory.

The Decalogue's prohibitions against murder, adultery, theft and even coveting are prohibitions against violating ownership, and thus predicates some concept of ownership. And it is probable that this concept did not differ from that of most humans: ownership is the extension of self. ${ }^{61}$ The owned is constitutive, as it were, of the owner's being, and vice versa. Even though the Lord God is ultimately the owner of everything and everyone - and human ownership, of course, is merely analogous to that of the Lord God - ancient Israel is thought to be the 'treasued possession' (Deut. 14:2) of the Lord God. And this special ownership relation is constitutive of ancient Israel (e.g. Lev. 20:26). For the ancient Israelites, therefore, ownership binds the owner and the owned together - the imago Dei, for instance, is owned by and own the Lord God.

The Decalogue's prohibitions against worship of other gods, blasphemy and rebellion against the laws of the Lord God are obligations to be free, and thus predicates some concept of freedom. And the introductory statement suggests that being free is being close to the Lord God, that is, being imago Dei. Idolatry, then, is the negation of freedom (e.g. Deut. 13), it is 'to sell' oneself into slavery (e.g. 2 Kings 17:16-17; cf. Deut. 28:68) - implying that, for the ancient Israelites, the concept of ownership and freedom were entangled. This conceptual connection between freedom and imago Dei makes sense: one can only be free when properly being that which one in fact is. And being imago Dei, as argued, consists in being willing and able to give and receive appropriate gifts, to uphold the order of creation and be creative within it.

It seems undisputable, therefore, that the ancient Israelite religious-political institutions were compatible with the gift-theory, which implies that the ancient Israelites could have been formed by its gist and thus experienced the emergence of an I-we. But is it likely that the ancient Israelites experienced the

6o Clements, Old Testament Theology, 168.

61 Belk, R.W. 'Possessions and the Extended Self'. Journal of Consumer Research, 15:2 (1988), 139-168: 144. 
emergence of an I-we? If so, then the gift theory must manifest itself in the ancient Israelite's collective psyche.

There is evidence of the gift theory - and the coming together of concepts like consummation, covenant, sacrifice, knowledge, love-fear, delight, holiness, glory, shalom - in the prophetic literature (esp. Hos. 2;6) as well as the wisdom literature (esp. Prov. 3:13-18; 9). Here, however, I shall argue that the narratives of the Tanakh in general, and the Akedah in particular, find their dramaturgical energy in the gift theory - which would give reasons to believe that the gift theory indeed describes a structure in the ancient Israelite's collective psyche.

In cutting covenant with Abraham, the Lord God promised that Abraham would receive blessings, land and progeny (Gen. 12:1-3); Abraham reciprocated the gift of faith. These are the gifts which constitute and substantiate the relationship between Abraham and the Lord God. And for Abraham, the promise of progeny is the Gift of these gifts. When dead and forgotten, land and blessings are of no significance. But to have progeny is to keep on living, to be remembered. For Abraham, then, the progeny embodies his inmost longings. It is not difficult, therefore, to imagine why Abraham and Sarah grew desperate with age. But at last, miraculously, the Lord God did as he promised: they received the gift of Isaac.

Then comes the absurd demand. 'Take your son, your only son Isaac, whom you love, and go the land of Moriah, and offer him there as a burnt offering' (Gen. 22:2). How could the Lord God make such a demand? And why?

Take your son, your only son Isaac. The repetitive style of the opening formulation draws attention to that which Isaac embodies. Not only is Isaac the son of Abraham, he is the only one - Isaac is the sole embodiment of Abraham's inmost longings. Thus, within the Lord God's demand, the reader-listener can identify an ambiguity of meaning. Does the Lord God demand the offering of Isaac qua son, 'the dearest in his life, whom he embraced'?62 Or does the Lord God demand the offering of Isaac qua symbol, that is, the embodiement of Abraham's inmost longings, who would make him honoured among his people, blessed in his kin, eternally remembered'?63

Take your only son Isaac, whom you love. We must be attentive to the emphasis on Abraham's 'love' (אהב). It is as if Abraham is being accused of loving Isaac, that he has to take Isaac simply because he loves him. Does the Lord God sadistically trial Abraham because of jealousy? That would be inconsistent

62 Kierkegaard, S. Fear and Trembling, transl. A. Hannay (London: Penguin Group, 2005), 21.

63 Kierkegaard, Fear and Trembling, 21. 
with the Lord God of the Tanakh, and we should therefore assume otherwise. When the Lord God is worshiped, burnt offerings become redundant - the Lord God longs for 'steadfast love' and 'knowledge' rather than 'burnt offering' (Hos. 6:6). However, the Lord God is indeed jealous when idols rather than the Lord God is worshiped (Ex. 34:14).

Take your only son Isaac, whom you love, and offer him. The very fact that the Lord God demands the burnt offering from Abraham suggests that the trial concerns Abraham's love for the Lord God, or lack thereof, rather than his love for Isaac. We must assume, therefore, that the Lord God demands the offering of Isaac qua symbol, rather than Isaac qua son. In his heart, Abraham worships that which Isaac qua symbol will give him, rather than worshiping the Lord God who gives. By demanding the offering of Isaac, the Lord God demands reciprocity of the Gift; the Lord God demands that Abraham reciprocates his inmost longings - that he surrenders all that is his to the Lord God.

Some might object, that to assume that Abraham has sinned by worshipping the gift rather than the Gift-giver is mere speculation. One can respond with Auerbach: the Akedah is mysterious. The Lord God's reasons for trialing Abraham, Abraham's psychological response to the Lord God's trial, the very meaning of the trial - all these are 'fraught with background; and therefore they require subtle investigation and interpretation, they demand it'.64 Moreover, the understanding that Abraham idolizes Isaac qua symbol is far more reasonable than the alternatives. And the fact that Abraham is to offer Isaac on Moriah makes this understanding all the more reasonable: the mountain foreshadows the Tabernacle, and with it, the notion that the Lord God's dwelling is predicated on the perpetuation of sacrifice.

This interpretation resolves many of the difficulties related to the Akedah. For instance, Abraham both sacrifices and does not sacrifice Isaac. That is, when Abraham returns from Moriah, something has been sacrificed, namely Isaac qua symbol, whereas Isaac qua son is redeemed - precisely because Isaac qua symbol has been sacrificed. Furthermore, this interpretation obtains novel observations and implications. Here I shall mention two.

First, in itself, the ram is not a complete substitute for Isaac. As Abraham journeys to Moriah, Abraham does in fact offer Isaac qua symbol. The three days of torment is a purifying judgment, gradually restoring Abraham's relation to the Lord God. This is captured in the verb 'offer' (עלה), which literally means

64 Auerbach, E. 'Odysseus' Scar', in Mimesis: The Representation of Reality in Western Literature (Princeton: Princeton University Press, 2003), 15. 
'rise up'. It is 'unclear'65 how one should apprehend such rising up: it might be plainly (e.g. the smoke of the offering) or metaphorically (e.g. the exalted presence of the Lord God) or perhaps both. Thus, some translators render the term 'restore' in non-sacrificial contexts (e.g. Jer. 8:22; 30:17). And the notion of restoration is closely related to offerings. Like making love, one sacrifices to 'draw near' (קרבן) the other. ${ }^{66}$ Such drawing near the other is to be transformed by the other - especially when the other is the Lord God. By offering Isaac qua symbol, Isaac qua son is restored as gift, that is, as the gift which binds the Lord God and Abraham together, the gift which constitutes and substantiates their relationship. When Abraham and Isaac climbs Moriah, the offering has already been made. The offering of the ram represents that which is completed: Isaac qua symbol has been offered, in faith that the Lord God, the keeper of promises, indeed will uphold Isaac qua son. Abraham's gift of faith thus restores qua transforms both his love for the Lord God and his love for Isaac; Abraham journeys home worshiping the Lord God as Gift-giver, and adoring and exalting Isaac as gift. The trial is thus about Abraham's relation to the Gift-giver and their gifts. When made aware of his idolatry, Abraham repents, and returns to worshiping the Gift-giver. Because the gifts constitute and substantiate the relationship between Abraham and the Lord God, the demand to reciprocate Isaac is also an invitation to deepen their relationship; the deeper the sacrifice, the deeper one is drawn together.

Second, by acting on the Lord God's demand, Abraham demonstrates - fearing and trembling - whom he worships: it is the Lord God qua the Gift-giver, who participates in mutual and absolute gift-dynamics. Thus, the Lord God's demand might appear absurd, but in reality - within the paradigm of the gift theory, against Abraham's cultural-historical background - it is perfectly sensible. That is, it is perfectly sensible within the logic of the gift-dynamics of Abraham and the Lord God. This might also explain why Abraham acts in solitariness, why Abraham speaks about the demand neither with Sarah nor Isaac. Sarah is not told because it is Abraham's Isaac that must be sacrificed, it is his idol, though Sarah, of course, might very well be guilty of similar idolatry. Isaac is not told because, in a sense, he is not the primary sacrifice; by sacrificing Isaac, Abraham sacrifices himself. Abraham is giving his all. That is, Abraham

65 Kellermann, D. 'עוֹלָָה/עלדה', in Theological Dictionary of the Old Testament Volume XI, ed. G.J. Botterweck, H. Ringgren \& H.-J. Fabry, transl. D.E. Green (Grand Rapids \& Cambridge: Wm. B. Eerdmans Publishing Co., 2004).

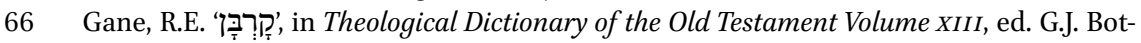
terweck, H. Ringgren \& H.-J. Fabry, transl. D.E. Green (Grand Rapids \& Cambridge: Wm. B. Eerdmans Publishing Co., 2004). 
does not only give his progeny; Abraham gives his life: to live without his only son - indeed having sacrificed his only son, his love and his hope - is worse than suffering death. The existential mayhem is comparable to that of Job, who regarded death as a blessing (Job 3:2-5).

On this interpretation of the Akedah, the dramaturgy finds its energy in the gift theory. To begin with, there is an equilibrium of gift-dynamics (singularity: $S$ ), then a collapse of the equilibrium (collapse: $C$ ), before a transformation of the equilibrium (transformation: $T$ ), which reestablishes an equilibrium of gift-dynamics (singularity: $S^{*}$ ) - and this is the grundstruktur. The closing of the cycle is not, however, a return to origin; rather, the original singularity is transformed. And buried in the ancient Israelites' rationalization about paramount historical religious-political events in the Tanakh, one finds this grundstruktur. As mentioned, all myths belong to a complex in which the structure of one myth will recur. "The structure that is common to all variations becomes apparent when different versions are "superimposed" one upon the other' ${ }^{67}$

Consider, for instance, the Chronicler's depiction of the origin of the temple. In Chronicles, David is portrayed in idealized terms; David personifies the monarchy. And for this reason, scholars have discussed the meaning of the census story in 1 Chronicles 21 . Why is the census depicted as sin by the Chronicler, when the other sins of David have been eradicated? Most scholars argue that the census story is concerned with the origin of the temple - and the positive value of the temple supersedes the negative value of David's sin. ${ }^{68}$ But the Chronicler could easily have edited the story, and told it without the sin. So why, one might question, did the Chronicler not? I believe the answer is this: how fitting it is to describe the origin of the temple in terms of sin - at the very same mountain that Abraham were to sacrifice Isaac (2. Chron. 3:1). Moreover, the sin is not just any sin, it is the archetypical sin of idolatry, of worshiping the gift rather than the Gift-giver. David received victories upon victories and reciprocated faith in God $(S)$. But rather than remaining faithful to the Giftgiver, David placed his faith in the gift: the army and its strength $(C)$. Upon being made aware of his idolatry, David confesses that 'I have sinned greatly'

67 Leach, 'Genesis as Myth', 22.

68 Braun, R. 1Chronicles: Word Biblical Commentary (Waco, Tex.: Word Books, 1986), 212218. For the opposing argument: Wright, J.W. 'The Innocence of David in 1 Chronicles 21'. Journal of Studies of the Old Testament 6o (1993), 87-105. For a response to the opposing argument: Baily, N. 'David's Innocence: A response to J. Wright'. Journal of Studies of the Old Testament 65 (1994), 83-9o. 
(1 $\mathrm{Chr} .21: 7)$, and he repents $(T)$. As he repents, the reader-listener is reminded of the Akedah by repetition of elements: burnt offering, angelic presence, and the provisions of the Lord God (1 Chr. 21:26-27) - elements which also betoken the dwelling of the Lord God. Moreover, the temple, where the Lord God 'was believed to reveal himself', ${ }^{69}$ is all about mutual and absolute gift-dynamics. 'For all things come from you, and of your own have we given you' (1 Chr. 29:14).

Thus, like the great patriarch, the great monarch commits the sin of worshiping the gift rather than the Gift-giver. And the same grundstruktur can be superimposed on the prophets' rationalization about the exodus and exile. When coming to Egypt, the people prospered $(S)$. But the people began to worship 'the idols of Egypt' (Ez. 20:7) rather than remaining faithful to the Lord $\operatorname{God}(C)$. Then the Lord God redeems the people, so as to give them his statues and observances $(T)$. But the people did not remain faithful, and embarked on cycles upon cycles of collapse and transformation - cycles which are elucidated by the Song's anthropology. The people continued to worship their idols, and was exiled to Babylon $(C)$. Then the Lord God yet again redeems his people, these 'makers of idols' (Isa. 45:16), restoring the gift-dynamics $(T)$.

These cycles of collapse and transformation are mere echoes, however, of the story in which the grundstruktur is most profoundly true: cosmic history. In the garden of Eden $(S)$, humans began to worship the gift rather than the Giftgiver $(C)$, and now these humans live through the trials of history $(T)$, longing for the cosmic singularity of the coming cosmic covenant $\left(S^{*}\right)$. The trials of history are unending variants of the Edenic temptation, that is, to idolize the gifts of the Lord God rather than the Lord God. To succumb to the temptation is to be estranged from the Lord God, to overcome is to be drawn closer to the Lord God.

The gift theory of the Song - that is, being imago Dei is to participate in mutual and absolute gift-dynamics - is compatible, then, with the religiouspolitical institutions of the ancient Israelites. Moreover, the gift theory describes a profound structure in their collective psyche. Thus, it is reasonable to conclude that the gift theory of the Song in particular, and ancient Israel in general, enabled the emergence of an I - or, rather, the emergence of I-we.

69 Clements, Old Testament Theology, 43. 